\title{
How can we reliably identify a taxon based on humeral morphology? - Comparative morphology of desmostylian humeri
}

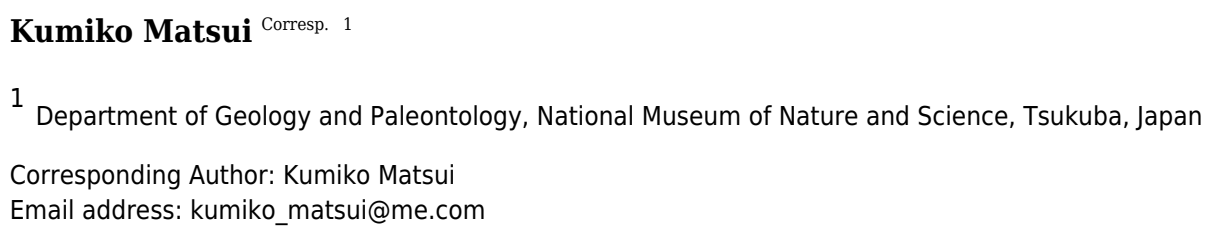

Desmostylia is a clade of marine mammals belonging to either Tethytheria or Perissodactyla. Rich fossil records of Desmostylia were found in the Oligocene to Miocene strata of the Northern Pacific Rim, especially in the northwestern region, which includes the Japanese archipelago. Fossils in many shapes and forms, including whole or partial skeletons, skulls, teeth, and fragmentary bones have been discovered from this region. Despite the prevalent availability of fossil records, detailed taxonomic identification based on fragmentary postcranial materials has been difficult owing to to our limited knowledge of the postcranial diagnostic features of many desmostylian taxa. In this study, I propose the utilization of diagnostic characters found in the humerus to identify desmostylian genus. These characters can be used to identify isolated desmostylian humeri at the genus level, contributing to a better understanding of the stratigraphic and geographic distributions of each genus. 


\section{How can we reliably identify a taxon based on humeral}

\section{2 morphology? -comparative morphology of desmostylian humeri-}

4 Kumiko Matsui ${ }^{1}$

5 1Department of Geology and Paleontology, National Museum of Nature and Science, 4-1-1

6 Amakubo, Tsukuba, Ibaraki, 305-0005, Japan.

7

8 Corresponding Author:

9 Kumiko Matsui ${ }^{1}$

10 4-1-1 Amakubo, Tsukuba, Ibaraki, 305-0005, Japan.

11 E-mail address: kumiko_matsui@me.com

12 


\section{Abstract}

15 Desmostylia is a clade of marine mammals belonging to either Tethytheria or Perissodactyla.

16 Rich fossil records of Desmostylia were found in the Oligocene to Miocene strata of the

17 Northern Pacific Rim, especially in the northwestern region, which includes the Japanese

18 archipelago. Fossils in many shapes and forms, including whole or partial skeletons, skulls, teeth,

19 and fragmentary bones have been discovered from this region. Despite the prevalent availability

20 of fossil records, detailed taxonomic identification based on fragmentary postcranial materials

21 has been difficult owing to to our limited knowledge of the postcranial diagnostic features of

22 many desmostylian taxa. In this study, I propose the utilization of diagnostic characters found in

23 the humerus to identify desmostylian genus. These characters can be used to identify isolated

24 desmostylian humeri at the genus level, contributing to a better understanding of the stratigraphic 25 and geographic distributions of each genus. 


\section{Introduction}

30 Desmostylia is a clade of extinct marine mammals (Repenning, 1965; Inuzuka 1984, 2000a, b;

31 Domning, 2002; Gingerich, 2005). At present, this clade is considered to belong to either

32 Tethytheria (Afrotheria; Domning, Ray \& McKenna., 1986) or Perissodactyla (Laurasiatheria;

33 Cooper et al., 2014). Their fossil records range from the Eocene/Oligocene boundary (Barnes and

34 Goedert, 2001) to the late Miocene (Barnes, 2013; Barboza et al., 2017). The last record of a

35 definite desmostylian fossil dates from the late Miocene (Barboza et al., 2017). However,

36 desmostylian remains have been found from Pliocene (Kimura, 1966). Many desmostylian fossils,

37 including whole skeletons, skulls, teeth, and bones, were discovered from both the east and west

38 sides of the North Pacific coast (Mitchell and Repenning, 1963; Mitchell, 1963; Shikama, 1966;

39 Chinzei, 1984; Inuzuka, 1984, 2000a; Barnes and Goedert, 2001; Hasegawa, Kimura \&

40 Matsumoto., 2006; Matsui and Kawabe, 2015).

41 Many diagnostic features of desmostylian genera and/or species have been proposed

42 based on the morphology of the skull, including the mandible and molar teeth (e.g. Reinhart,

43 1959; Domning, Ray \& McKenna., 1986; Inuzuka, 1989, 2000; Beatty, 2009; Chiba et al., 2016;

44 Beatty and Cockburn, 2016; Santos et al., 2016). Inuzuka (2000, 2013), for example, proposed

45 many diagnostic features in the cranial and postcranial morphology for the genera Desmostylus

46 and Paleoparadoxia. However, some of the proposed diagnostic features are ambiguous. There

47 were no obvious criteria on qualitative traits. In addition, only remains of Desmostylus and

48 Paleoparadoxia had been reported from the Miocene in Japan when his papers were published.

49 Subsequently, another genus cf. "Vanderhoofius" sp. was described by Chiba et al. (2016) based

50 on material from Hokkaido. Santos et al. (2016) provided an updated ontogenetic sequence for 
51 Desmostylus as well as features diagnostic of advanced age specimens based on mandibular

52 morphology. Additionally, Santos et al. (2015) also synonymized Vanderhoofius with

53 Desmostylus. Furthermore, Barnes (2013) divided the genus Paleoparadoxia into three genera,

54 Archaeoparadoxia, Paleoparadoxia, and Neoparadoxia. His taxonomic scheme has been

55 accepted in many studies on desmostylians (e.g. Beatty and Cockburn, 2015; Matsui and

56 Kawabe, 2015; Chiba et al., 2016). Accordingly, the taxonomy of Japanese desmostylian from

57 the Miocene needs to reflect this scheme, necessitating the establishment of diagnostic features

58 for these three new genera. However, diagnostic features of Paleoparadoxia that were previously

59 proposed by Inuzuka (2000, 2005 and 2013) have been applied to be specific for Neoparadoxia

60 after Barnes (2013) split the genus into three. Therefore, postcranial diagnostic features of

61 Paleoparadoxia sensu stricto have not been discussed in past studies except for those by

62 Shikama (1966) and Matsui and Kawabe (2015). On the other hand, there are some localities

63 where multiple desmostylian genera were found from a single bed (e.g., Akan area; Kimura et

64 al., 1998; Sato and Kimura, 2002; Watanabe and Kimura, 2002; Yoshida and Kimura, 2002) or

65 similar horizons (e.g., Mizunami area, Gifu, Japan; Yoshiwara and Iwasaki, 1902; Tokunaga and

66 Iwasaki, 1914; Ijiri and Kamei, 1960; Shikama, 1966; Kamei and Okazaki, 1974; Okazaki, 1977;

67 Kohno, 2000). In such cases, it is particularly important to precisely identify desmostylian genera

68 for recognizing their taxonomic diversity and establish detailed diagnostic characters for each

69 genus. To rectify the current situation, a detailed comparison was made of the morphology of the

70 humerus in the present study. As a result, diagnostic features in the humerus are proposed for

71 each desmostylian genus. 


\section{Institutional Abbreviations}

73 AMP: Ashoro Museum of Paleontology, Hokkaido, Japan; GSJ: Geological Survey of Japan,

74 Ibaraki, Japan; LACM: Los Angeles County Museum, Los Angeles, USA; NMNS, NSMT:

75 National Museum of Nature and Science, Tokyo, Japan; OME: Okhotsk Museum Esashi, 1614-1

76 Mikasa-cho, Esashi, Hokkaido, Japan ;RBCM: Royal British Columbia Museum, Victoria,

77 British Columbia, Canada; SMNH: Saitama Museum of Natural History, Saitama, Japan;

78 UCMP: University of California Museum of Paleontology, Berkeley, California, USA; UHR:

79 Hokkaido University Museum, Sapporo, Japan; UMUT: The University Museum, The

80 University of Tokyo, Tokyo, Japan. 
81

82

\section{Materials and Methods}

83

84 Specimens and references

85 In this study, I analyzed morphologies of desmostylian humeri, as well as those of potential 86 outgroups of Desmostylia, based on direct examinations of specimens or literature reviews. The 87 following specimens and references were used in this study (Fig 1).

$88 \quad$ 1. Desmostylia

89 1-1. Desmostylidae

90 1-1-1. Ashoroa laticosta

91 AMP 21, nearly complete left and right humeri of Ashoroa laticosta from the late Oligocene

92 Morawan Formation, Kawakami Group, Hokkaido, Japan, described by Inuzuka (2000b, 2011).

93 This specimen is the holotype of A. laticosta. AMP 21 shows the epiphyseal fusion in the humerus 94 and is considered as an adult (Hayashi et al., 2013; Barnes, 2013).

95 1-1-2. Desmostylus hesperus

96 - UHR 18466, a nearly complete left humerus of $D$. hesperus from the Middle Miocene 97 Uchiboro coal-bearing Formation, Sakhalin, Russia. This specimen was the type specimen 98 for D. mirabilis (Nagao, 1935), which was redescribed by Inuzuka (1982) and later 99 synonymized with $D$. hesperus by Inuzuka et al. (1994). UHR 18466 shows the epiphyseal 100 fusion in the humerus and is considered as an adult (Hayashi et al., 2013).

101 - GSJ-F7743, nearly complete left and right humeri of $D$. hesperus from the middle Miocene 102 Tachikaraushinai Formation, Japan, described by Inuzuka (2009). GSJ-F7743 does not show 103 neurocentral fusion of vertebrae or epiphyseal fusion in long bones and is considered as a 
104 juvenile (Hayashi et al., 2013).

105 - OME-U-0170, nearly complete but proximal end was lacked, is a right humerus of $D$.

106 hesperus from the middle Miocene Tachikaraushinai Formation, Japan. This specimen was

107 described by Inuzuka et al. (2016). OME-U-0170 shows the epiphyseal fusion in the humerus

108 and is considered as an adult.

109 1-1-3. Demostylus sp.

110 Demostylus sp., distal part of the humerys of Desmostylus sp. from the Middle Miocene

111 Chikubetsu Formation, Japan, housed in Obira City Historical Museum and reported by Nakaya,

112 Watabe \& Akamatsu (1992). This specimen shows epiphyseal fusions in the humerus and is

113 considered as an adult.

114 1-2. Paleoparadoxiinae

115 1-2-1. Archaeoparadoxia weltoni

116 UCMP114285, incomplete and fragmentary right and left humeri of Archaeoparadoxia weltoni

117 (Clark, 1991) from the late Oligocene or early Miocene Skooner Gulch Formation, California,

118 USA. UCMP114285 has M3 with occlusal surface and is considered as an adult.

119 1-2-2. Paleoparadoxia tabatai

120 NMNS PV-5601, an incomplete left humerus of Paleoparadoxia tabatai (Tokunaga, 1939) from

121 the early Miocene Mizunami Group, Gifu, Japan, designated as the neotype of this species by

122 Shikama (1966). NMNS PV-5601 shows epiphyseal fusions in the humerus and is considered as

123 an adult (Hayashi et al., 2013; Barnes, 2013).

124 1-2-3. Paleoparadoxia sp.

125 - SMNH VeF-61, a nearly complete left humerus of Paleoparadoxia sp. from the lower

126 Miocene in the Chichibu Basin, Saitama, Japan, described by Saegusa (2002). SMNH VeF- 
12761 shows epiphyseal fusions in the humerus and is considered as an adult.

128 UMUT CV31059, a proximal part of the right humerus of Paleoparadoxia sp. from the early

129 Miocene Sankebetsu Formation, Hokkaido, Japan, described by Matsui and Kawabe (2015).

130 UMUT CV31059 shows epiphyseal fusions in the humerus and is considered as an adult.

131 - AMP AK1002, a right humerus of Paleoparadoxia sp. from the middle Miocene Tonokita

132 Formation, Hokkaido, Japan. This specimen was used by Hayashi et al. (2013). AMP

133 AK1002 shows epiphyseal fusions in the humerus and is considered as an adult (Hayashi et

134 al., 2013).

\section{1-2-4. Neoparadoxia cecilialina}

136 LACM 150150, nearly complete right and left humeri from the lower upper Miocene Monterey

137 Formation in California, USA. Epiphyses in humeri of LACM 150150 are not fused and the 138 specimen is thus considered as a juvenile (Barnes, 2013).

139 1-2-5. Neoparadoxia repeninngi

140 NMNS PV 20731, distal end of left humerus from the middle Miocene Ladera Formation in

141 California, USA. Epiphyses of whole skeleton were fused and the specimen is considered as an 142 adult.

$143 \quad 1-3 . \quad$ family indeterminate

144 1-3-1. Behemotops cf. proteus (Beatty and Cockburn, 2015)

145 RBCM.EH2007.008.0001, a nearly complete left humerus from the late Oligocene of Vancouver

146 Island, British Columbia, Canada, reported by Beatty and Cockburn (2015).

147 RBCM.EH2007.008.0001 shows epiphyseal fusions in the humerus and is considered as an adult. 148

$1492 . \quad$ Out groups 
150 2-2. Tethytheria

$151 \quad 2-2-1 . \quad$ Sirenia

152 2-2-1-1. Halithriinae gen. sp. indet.

153 NMNS PV-20171, a left humerus of Halitheriinae from the late Miocene Aoso Formation, Miyagi, 154 Japan. NMNS PV-20171 shows epiphyseal fusions in the humerus and is considered as an adult.

155 2-2-1-2. Hydrodamalis cuestae

156 NMNS PV-21914, a cast of the right humerus of Hydrodamalis cuestae (SDSNH 35293;

157 Domning, 1978) from the early Pleistocene San Diego Formation (Member 2), California, USA.

158 NMNS PV-21914 shows epiphyseal fusions in the humerus and is considered as an adult.

159 2-2-1-3. Dugong dugon

160 NSMT M-24886, a right humerus. NSMT M-24886 shows epiphyseal fusions in the humerus and 161 is considered as an adult.

162 2-2-1-4. Trichechus manatus lastralis

163 NSMT M-35016, a left humerus from USA. NSMT M-35016 shows epiphyseal fusions in the 164 humerus and is considered as an adult.

165

166 2-3. Perissodactyla

167 2-3-1. Equidae (Harmanson and MacFadden, 1992; Kato and Yamauchi, 2003)

168 Mesohippus, Merychipps, Hypohippus, Dinohippus and Equus spp. illustrated in Harmanson and

169 MacFadden (1992) and Kato and Yamauchi (2003). All specimens are adults.

170 2-3-2. Taipiridae (Harmanson and MacFadden, 1992)

171 Tapirus terrestris, illustrated in Harmanson and MacFadden (1992). This is an adult specimen.

172 2-3-3. Rhinocerotidae (Harmanson and MacFadden, 1992) 
173 Diceros bicornis, illustrated in Harmanson and MacFadden (1992). This is an adult specimen.

174

The anatomical terminology follows Kato and Yamauchi (1995). Terminologies of

175 humorous are illustrated in Fig 2.

176 
179 Comparisons of humeral morphology between desmostylians and their outgroups

181 In general, the desmostylian humerus has a wide, oval, and large articular surface, as well as a 182 large trochlea. The diaphysis of the humerus is straighter than those in Dugongidae and

183 Trichechidae (Sirenia). It is also larger than the one in Dugongidae. The intertubercular groove is

184 shallower and narrower in Desmostylia than in Perissodactyla. Large Perissodactyla, Equidae

185 (larger species than Hypohippus) and Rhinocerotidae (Diceros bicornis) have two intertubercular 186 grooves and are thus very distinct from that in desmostylians. In small Perrisodactyla (Equidae

187 smaller than Merychippu and Tapiridae), the greater tubercle is more developed and extended to 188 the cranial side than in demostylians; this is the feature that clearly distinguishes this taxon from 189 desmostylians. The humeral heads of desmostylians are oval-shaped in contrast to the semi-

190 spherical ones in Trichechidae and Hydrodamalis. The lesser tubercle is developed in

191 desmostylians, but the one in Trichechidae is fused with the greater tubercle. The greater tubercle

192 is strongly developed and extends to the lateral side of the humerus in Dugongidae, whereas the

193 one in desmostylians is not strongly developed on the lateral side. Additionally, dugongids have

194 a well-developed stylate deltoid tuberosity, whereas desmostylians do not have an apparent

195 deltoid tuberosity as do Dugongidae or Perissodactyla.

\section{Behemotops}

198 The diaphysis in Behemotops is thinner than those in other desmostylians. The greater tubercle 199 extends higher than the head of the humerus in Paleoparadoxia and Ashoroa. The height of this 
200 tubercle in Behemotops is almost the same as the one in Ashoroa, but smaller than the one in

201 Paleoparadoxia. The curvature of the diaphysis is the greatest among desmostylians, curved along

202 both the mediolateral side (as in Ashoroa) and the caudal side (as in Trichechus and

203 Hydrodamalis). The angle of the head of the humerus is greater than those in Ashoroa,

204 Desmostylus, Paleoparadoxia and is almost the same as that in Neoparadoxia. The intertubercular

205 groove and lesser tubercle are not well preserved in the observed specimens of Behemotops. The

206 line of attachment for the triceps muscle is not clear, unlike in Paleoparadoxia and Neoparadoxia,

207 and is rather similar to the one in Dugong dugon. The humeral neck of Behemotops is shallower

208 than that of other desmostylians. The humeral crest is as weak as that in Paleoparadoxia but longer

209 than those in Paleoparadoxia and Neoparadoxia. However, it is slightly shorter than those in

210 Ahoroa and Desmostylus.

211

212 3. Archaeoparadoxia

213 The preservation condition of Archaeoparadoxia humeri is poor, so parts available for

214 comparison are limited. The diaphyses of the right and the left humeri are not preserved

215 completely and thus incomparable. The humeral morphology of Archaeoparadoxia is similar to

216 that of Ashoroa and Paleoparadoxia in general. The diaphyses of the right and the left humeri

217 are curved less craniomedially than Ashoroa and Behemotops, different from Neoparadoxia,

218 Paleoparadoxia, and Desmsotylus. The head of the humerus is oval-shaped and slightly convex

219 at the distal end, similar to that in Paleoparadoxia. The lesser tubercle is distinct and medially

220 projected, located on the medial side like Paleoparadoxia and different from that in Ashoroa.

221 The greater tubercle is wider than that of Behemotops but more slender than that of

222 Neoparadoxia. The lateral epicondyle is more developed and medially projected than that in 
223 Ashoroa. The trochlea is incomplete, smaller than that of paleoparadoxiids and desmostylids, and

224 obliquely tilted. However, it is unknown whether the original characters are preserved in this

225 fossil specimen.

226

227 4. Neoparadoxia

228 The lesser and greater tubercle epiphyses are not preserved in N. cecilialina and N. repeninngi,

229 but the direction of development and approximate size are comparable. The humeral morphology

230 of Neoparadoxia is similar to that of Paleoparadoxia in general. The humerus of Neoparadoxia

231 has a thick shaft, similar to the one found in Paleoparadoxia. The humeral crest is longer,

232 extends more distally, and is more strongly developed than that in Paleoparadoxia. The head of

233 the humerus is oval in shape and is horizontally longer than those in Paleoparadoxia, Ashoroa,

234 and Desmostylus.

5. Ashoroa

237 In general, the humeral morphology of Ashoroa is similar to that of Paleoparadoxia and

238 Archaeoparadoxia. The lesser tubercle does not project to the medial side and is developed on

239 the cranial side. The lesser tubercle is developed to cover the intertubercular groove and is

240 morphologically similar to those in small-sized equids (e.g., Mesohippus and Merychippus). The

241 humeral crest of Ashoroa is prominent and is developed higher and longer than in

242 Paleoparadoxia and Neoparadoxia. It is also more robust than that in Paleoparadoxia and

243 Behemotops.

244

245 6. Desmostylus 
246 The humeral morphology of Desmostylus is very different from that in other desmostylians,

247 especially its intertubercular groove. The intertubercular groove of Desmostylusis located behind

248 the head of the humerus. It is also wider and more shallow than the ones found in other

249 desmotylians. In addition, the lesser tubercle is not knobby, unlike those in other desmostylians.

250 The humeral crest extends distally more than the proximal half of the diaphysis and thus

251 different from those in Paleoparadoxia and Neoparadoxia. However, it appears to be similar to

252 those in Behemotops and Ashoroa. The development of the humeral crest is greater than in

253 Paleoparadoxia and Behemotops. The height of the greater tubercle is the same as that of the

254 head of the humerus, differentiating it from those in Paleoparadoxia, Ashoroa, and Behemotops.

255 The constriction of the diaphysis is less developed than that in Ashoroa, Behemotops,

256 Neoparadoxia, and Paleoparadoxia.

257

258 Diagnostic characters of desmostylian humeri

259 Based on the description and comparison presented above, the following combinations of

260 diagnostic characters are proposed for each taxon.

261

262 1. Desmostylia (Figure 3)

263 1. Humerus diaphysis thicker than that in other relatives

264 2. Head of humerus larger than that in other relatives

2653 . Articular facet of head of humerus wider than in other relatives

266 4. Greater tubercle larger than other that in relatives

267 5. Almost straight humerus diaphysis 
268 6. Trochlea larger than that in other relatives

269

270 2. Behemotops (Figure 4)

271 1. Humeral diaphysis thinner than that in other desmostylians

272 2. Diaphysis curved on both mediolateral and caudal sides as in Trichechus

273 3. Head of humerus with larger angle than that in other desmostylians

274 4. Shortest intertubercular groove in desmostylians

275 5. Greater tubercle extending dorsally higher than head of humerus (lower than that in

276 Paleoparadoxia, higher than that in Desmostylus, and similar to that in Ashoroa)

277 6. Humeral neck shallower than that in other desmostylians

278

279 3. Archaeoparadoxia (Figure 5)

280 1. Greater tubercle extending toward proximal side above the head of the humerus as in $281 \quad$ Paleoparadoxia

282 2. Wider greater tubercle than that in Desmostylus and Behemotops

283 3. Lesser tubercle distinct and smaller than that in Paleoparadoxia and medially projected,

284 located on medial side like that in Paleoparadoxia

285 4. Intertubercular groove located on medial side and shallower than that in Neoparadoxia

286 5. Trochlea smaller than that in desmostylids and other paleoparadoxiids, but slightly larger

287 than trochlea of Behemotops

288 6. Diaphysis slightly curved mediolaterally and caudally, unlike those of Paleoparadoxia and

289 Desmostylus, but weaker than those of Ashoroa and Behemotops 
291 4. Paleoparadoxia (Figure 6; proposed by Matsui and Kawabe, 2015)

292 1. Greater tubercle extending toward proximal side above the head of the humerus

293 2. Greater tubercle wider than that in Desmostylus and Behemotops

294 3. Lesser tubercle distinct and medially projected, located on medial side

295 4. Intertubercular groove located on medial side

296 5. Shallow and narrow intertubercular groove

297 6. Head of humerus oval-shaped and slightly convex at distal end

298 7. Absence of well-developed deltoid tuberosity

299

300 5. Neoparadoxia (Figure 7)

301 1. Greater tubercle developed as crest, stronger than that in in Paleoparadoxia

302 2. Humeral crest strongly developed and extending distally over half of whole humerus

303 3. Head of humerus oval, wider than that in Paleoparadoxia, and not convex at distal end

$304 \quad$ unlike in the Paleoparadoxia

305 4. Intertubercular groove wider than that in Paleoparadoxia, but narrower than that in

306 Desmostylus

307

308 6. Ashoroa (Figure 8)

309 1. Constriction of humeral neck shallower in desmostylians, but deeper than that in

$310 \quad$ Behemotops

311 2. Lesser tubercle only slightly less developed than that in Archaeoparadoxia,

312 Paleoparadoxia, and Neoparadoxia 
313 3. Intertubercular groove shorter than that in Archaeoparadoxia, Paleoparadoxia,

$314 \quad$ Neoparadoxia, and Desmostylus

315 4. Diaphysis loosely curved like that in Behemotops, but stronger than that in

$316 \quad$ Archaeoparadoxia

317 5. Humeral crest more strongly developed than that in Paleoparadoxia and extending distally

$318 \quad$ just above trochlea

319 6. Lesser tubercle located and developed on cranial side

320

321 7. Desmostylus (Figure 9)

322 1. Intertubercular groove located just behind head of humerus on cranial side

323 2. Shallow and v-shaped intertubercular groove

$3243 . \quad$ Lesser tubercle smaller than that in other desmostylians

325 4. Lesser tubercle not projecting to medial and cranial sides

326 5. Crest of lesser tubercle well-developed and extending ventrally

327 6. Greater tubercle and head of humerus almost the same height (= greater tubercle not

$328 \quad$ projecting higher than head of humerus)

329 


\section{Discussions}

332

333 Humeral characteristics of desmostylians differ in each genus. These characters are thus

334 sufficient for genus-level identification. The morphologies of the Desmostylus humerus are quite

335 different from those in other desmostylians. The extension of the greater tubercle is shorter than

336 that in other desmostylians. Additionally, the position of the intertubercular groove is right

337 behind the head of humerus and very shallow compared to that in other desmostylians. These

338 differences approximately correspond to the differences between the humeri of manatees and

339 dugongs. Dugongs have a greater tubercle that is higher than the head of humerus and do not

340 have an intertubercular groove that is opened right at the back of the head of the humerus, unlike

341 manatees. The humeri of manatees show some morphological variability. Florida manatees

342 (Trichechus manatus) exhibit variation in the intertubercular groove. Nineteen percent of the

343 Florida manatees and all Amazon manatees (Trichechus inunguis) have an intertubercular

344 groove, while it is absent from in other manatees (Domning and Hayak, 1986). The

345 ntertubercular grooves of Amazon manatees are more distinct than those of Florida manatees

346 (Domning and Hayek, 1986). These differences result from distinct biceps bracii muscles in

347 Amazon manatees (Domning and Hayek, 1986). In sirenians, the hind limbs are virtually absent

348 and locomotion is accomplished by vertical movement of the tail (Berta et al., 2016). However,

349 their locomotory use of flippers is different. Dugongs swim in the sea and use their forelimbs

350 only for cruising (Berta et al., 2016), but manatees use their forelimb to "walk" on the sea floor

351 (Hartman, 1979). In Desmostylia, Inuzuka (2013) indicated that Paleoparadoxiinae has more

352 movable coxae than do Desmostylus. However, differences in hind limbs locomotion among

353 desmostylians have not been reported. Therefore, it has been suggested that the hind limbs of 
354 desmostylians have similar movements (Inuzuka, 2005). Based on fossil evidence, the humeral

355 characteristics between Desmostylus and other desmostylian would likely lead to differences in

356 swimming behavior, similar to what we observe in dugongs and manatees.

357

358 Remaining issues

359 The holotype of Desmostylus hesperus, the type species of the genus, includes only a

360 fragmentary molar and also does not include a humerus. Therefore, it is impossible to distinguish

361 the proposed species of Desmostylus based solely on the observed diagnostic features of the

362 holotype specimens. Accordingly, re-designating a specimen with skulls and forelimbs bearing

363 sufficient diagnostic characters as neotypes for species of $D$. hesperus should be considered. A

364 similar issue has been discussed for Coelophysis bauri, a theropod dinosaur (Hunt and Lucus,

365 1991; Colbert et al. 1992).

366 In addition, there are only six desmostylian genera, for which humeri were found in

367 association with molars or skulls that allow us to realize taxonomic identification at the genus or

368 species level. In other words, no postcranial skeletons are known for many desmostylian genera

369 or species. Accordingly, when new specimens are found in the future, the diagnostic characters

370 proposed here would need to be evaluated and revised to reflect the new information. 


\section{Conclusion}

373

374 Here I present the newly established diagnostic features of desmostylian humeri. There were not

375 many differences observed between humeral morphologies of different species of desmostylians,

376 except for Desmostylus. However, these minor differences are enough to distinguish different

377 desmostylian genera. This study will be important for taxonomic corrections and detailed

378 classifications. Higher resolution and accurate classification than that has been previously

379 accomplished, even for partial postcranial skeletons, would be able to achieve if new postcranial

380 elements are identified that have highly diagnostic features. This will provide useful information

381 for the paleogeography and distribution range of Desmostylia.

382 


\section{Acknowledgements}

385 I am grateful to H. Naruse (Kyoto University), T. Tsuihiji (The University of Tokyo), S. Kawabe

386 (FDPM) for their helpful advice. Thanks are also due to N. Kohno, T. Yamada, Y. Tajima

387 (NMNS), N. Kaneko (GSJ), Y. Kobayashi, T. Tanaka (UHR), T. Ando, T. Sawamura, T. Shinmura

388 (AMP), O. Sakamoto and H. Kitagawa (SMNH), M. Nagasawa (Obira Town), M. B. Goodwin 389 and P. Holroyd (UCMP), J. Vélez-Juarbe, S. McLead, V. R. Rhue (LACM) for access to specimens

390 under their care. I also thank to Masamichi Ara (The University of Tokyo) for helpful advice to

391 improve this article. Finally, thanks to the handling editor J. Hutchinson, referees B. L. Beatty and

392 G. P. Santos for constructive comments and suggestions.

393

394 


\section{References}

396

397 Barboza, M. M., Parham, J. F., Santos, G. P., Kussman, B. N., Velez-Juarbe, J. 2017. The age of 398 the Oso member, Capistrano formation, and a review of fossil crocodylians from California. PaleoBios 34: 1-16.

Barnes, L. G. 2013. A new genus and species of Late Miocene paleoparadoxiid (Mammalia, 401 Desmostylia) from California. Contributions in Science 521: 51-114

Barnes, L. G. and J. L. Goedert. 2001. Stratigraphy and Paleoecology of Oligocene Desmostylian 403 Occurrences in Western Washington State, U.S.A. Bulletin of Ashoro Museum of 404 Paleontology 2: 7-22.

Beatty, B. L. 2009. New material of Cornwallius sookensis (Mammalia: Desmostylia) from the 406 Yaquina Formation of Oregon. Journal of Vertebrate Paleontology 29: 894-909 DOI

Beatty, B. L. and Cockburn, T. C. 2015. New insights on the most primitive desmostylian from a $10.1671 / 039.029 .0320$ partial skeleton of Behemotops (Desmostylia, Mammalia) from Vancouver Island, British Columbia. Journal of Vertebrate Paleontology 35: e979939 DOI $10.1080 / 02724634.2015 .979939$. Michael, P. J and Tanaka, K. 2016. A new desmostylian mammal from Unalaska (USA) and the robust Sanjussen jaw from Hokkaido (Japan), with comments on feeding in derived desmostylids. Historical Biology 28: 289-303 DOI 10.1080/08912963.2015.1046718.

417 Chinzei, K. 1984. Modes of occurrence, geologic ranges and geographic distribution of 
418

419

420

421

422

423

424

425

426

427

428

429

430

431

432

433

434

435

436

437

438

439

440

desmostylians. Monograph of the Association for the Geological Collaboration in Japan 28: 13-23.

Clark, J. 1991. A new early Miocene species of Paleoparadoxia (Mammalia: Desmostylia) from California. Journal of Vertebrate Paleontology 11: 490-508 DOI 10.1080/02724634.1991.10011417.

Colbert, E.H., Charig, A.J., Dodson, P., Gillette, D.D., Ostrom, J.H., and Weishampel, D. 1992. Coelurus bauri COPE, 1887 (currently Coelophysis bauri: Reptilia, Saurischia): proposed replacement of the lectotype by a neotype. Bulletin of Zoological Nomenclature 49: 276-279.

Cooper, L. N., Seiffert, E. R., Clementz, M., Madar, S. I., Bajpai, S., Hussain, S. T., and Thewissen, J. G. 2014. Anthracobunids from the middle Eocene of India and Pakistan are stem perissodactyls. PloS one 9: e109232 DOI 10.1371/journal.pone.0109232.

Domning, D. P. 2002. The terrestrial posture of desmostylians. Smithsonian Contribution to Paleobiology 93: 99-111.

Domning, D. P. 1978. Sirenian evolution in the northern Pacific Ocean. University of California Publications in Geological Sciences 118: 1-176.

Domning, D. P., Ray, C. E. and McKenna, M. C. 1986. Two New Oligocene Desmostylians and a Discussion of Tethytherian Systematics. Smithsonian Contributions to Paleobiology 59: 1-56 DOI 10.5479/si.00810266.59.1.

Gingerich, P. D. 2005. Aquatic adaptation and swimming mode inferred from skeletal proportions in the Miocene desmostylian Desmostylus. Journal of Mammalian Evolution 12: 183194 DOI 10.1007/s10914-005-5719-1.

Hasegawa, Y., Kimura, T. and Matsumoto. R. 2006. A smaller manus of the Paleoparadoxia 
441

442

443

444

445

446

447

448

449

450

451

452

453

454

455

456

457

458

459

460

461

462

463

(Mammalia: Desmostylia) from the Haratajino Formation, Tomioka Group, Gunma, Japan. Bulletin of Gunma Museum of Natural History 10: 37-48.

Hayashi, S., Houssaye, A., Nakajima, Y., Chiba, K., Ando, T., Sawamura, H., Inuzuka, N., Kaneko, N., Osaki, T. 2013. Bone inner structure suggests increasing aquatic adaptations in Desmostylia (Mammalia, Afrotheria). Plos One 8: e59146 DOI 10.1371/journal.pone.0059146.

Hermanson, J. W. and MacFadden, B. J. 1992. Evolutionary and functional morphology of the shoulder region and stay-apparatus in fossil and extant horses (Equidae). Journal of Vertebrate Paleontology 12: 377-386 DOI 10.1080/02724634.1996.10011321.

Hunt, A. P., Lucas, S. G. 1991. Rioarribasaurus, a new name for a Late Triassic dinosaur from New Mexico (USA). Paläontologische Zeitschrift 65: 191-198 DOI 10.1007/BF02985783.

Ijiri, S., Kamei, T. 1961. On the skulls of Desmostylus mirabilis Nagao from South Sakhalin and of Paleoparadoxia tabatai (Tokunaga) from Gifu Prefecture, Japan. Earth Science 53: 1-27.

Inuzuka, N. 1982. The skeleton of Desmostylus mirabilis from South Sakhalin 5. Limb bones. Earth Science 36: 117-127.

Inuzuka, N. 1984. Skeletal restoration of the Desmostylians: Herpetiform Mammals. Memoirs of the Faculty of Science, Kyoto University. Series of biology 9: 157-253.

Inuzuka, N. 1988. The skeleton of Desmostylus from Utanobori, Hokkaido, 1. Cranium. Bulletin of the Geological Survey of Japan 39: 139-190.

Inuzuka, N. 2000a. Research trends and scope of the order Desmostylia. Bulletin of the Ashoro Museum of Paleontology 1: 9-24. 
464 Inuzuka, N. 2000b. Primitive Late Oligocene Desmostylians from Japan and Phylogeny of the 465 Desmostylia. Bulletin of the Ashoro Museum of Paleontology 1: 91-124.

466 467 468 469 470 471 472 473 474 475 476 skeleton. Bulletin of the Geological Survey of Japan 60: 257-379.

Inuzuka, N. 2011. The postcranial skeleton and adaptation of Ashoroa laticosta (Mammalia: Desmostylia). Bulletin of the Ashoro Museum of Paleontology 6: 3-57.

Inuzuka, N. 2013. Reconstruction and life restoration of Desmostylus and Paleoparadoxia. Journal of Fossil Research 45: 31-43.

Inuzuka, N., Kaneko, N., Takabatake, T. 2016. The skeleton of Desmostylus from Utanobori, Hokkaido, Japan, III. Redescription of the 8th Utanobori specimen and reconsideration for cranial morphology of the 1st specimen. Bulletuin of Geolological Survey of Japan 67: $167-181$.

Kato, K., Yamauchi, S., 1995: Domestic Animal Comparative Anatomy Atlas 1, 482 p. Yokendo Corporation, Tokyo.

Kamei, T., Okazaki, Y. 1977. Mammalian fossils from the Mizunami Group, central Japan (Part 2). Bulletin of the Mizunami Fossil Museum 4: 9-24.

Kimura, M. 1966. Discovery of Desmostylian Molar from Rawan Conglomerate Sandstone Member, Honbetu cho, Nakagawa gun, Hokkaido. Earth Science 31: 167-170.

Kimura, M., Yahata, M., Sawamura, H., Segawa, I., Suzuki, A., and Muraishi, Y. 1998. The vertebrate Fossils and their horizon from Akan-cho, eastern Hokkaido, Japan. Earth Science 52: 44-50.

Kohno, N. 2000. A centenary of studies on the holotype (NSM-PV 5600) of Desmostylus japonicus Tokunaga and Iwasaki, 1914. Bulletin of Ashoro Museum of Paleontology 1: 137-151. 
487 Marsh, O. C. 1888. Notice of a new fossil sirenian from California. American Journal of Science

488

489

490

491

492

493

494

495

496

497

498

499

500

501

502

503

504

505

506

507

508

509

35: 94-96 DOI 10.2475/ajs.s3-35.205.94.

Matsui, K. and Kawabe, S. 2015. The Oldest Record of Paleoparadoxia from the Northwest Pacific with an Implication on the Early Evolution of Paleoparadoxiinae (Mammalia: Desmostylia). Paleontological Research 19: 251-265 DOI 10.2517/2015PR007.

Mitchell, E. D. Jr., Lipps, J. H. 1965. Fossil collecting on San Clemente Island. Pacific Discovery 18: $2-8$.

Mitchell, E. D., Repenning, C. A. 1963. The chronologic and geolographic range of desmostylians. Contributions in Science 78: 1-20.

Nagao, T. 1935. Desmostylus mirabilis nov. from Sakhalin. Journal of Geological Society of Japan 42: $822-824$.

Nakaya, H., Watabe, M., Akamatsu, M. 1992. A New Miocene Desmostylia (Mammalia) from Obira cho, Hokkaido, Northerm Japan (Preliminary Report). Abstracts of the Regular Meeting of the Palaeontological Society of Japan 141: 20.

Reinhart, R. H. 1959. A review of the Sirenia and Desmostylia. University of California Publications in Geological Sciences 36: 1-146

Repenning, C. A. 1965. Drawing of Paleoparadoxia skeleton. Geotimes 9: 1-3.

Saegusa, H. 2002. A partial skeleton of Paleoparadoxia from San-yama, Ogano-cho, Saitama Prefecture, central Japan. Nature and Human Activities 7: 1-25.

Santos, G. P., Parham, J. F., Beatty, B. L. 2016. New data on the ontogeny and senescence of Desmostylus (Desmostylia, Mammalia). Journal of Vertebrate Paleontology 36: e1078344 DOI 10.1080/02724634.2016.1078344.

Sato, A., Kimura, M. 2002. Description and taxonomy of desmostylian fossils at 1st site in 1998. 
512 Shikama, T. 1966. Postcranial Skeletons of Japanese Desmostylia. Palaeontological Society of Japan Special Paper 12: 1-202.

514 Tokunaga, S. 1939. A new fossil mammal belonging to the Desmostylidae.. In: Institute of

515

516

517

518 Tokunaga, S. and Iwasaki, C. 1914. Notes on Desmostylus japonicus. Journal of the Geological 519

520 521

522

523

524 525

526

527 528 Science, Imperial University of Tokyo 16: 1-13. Geology and Paleontology, Tohoku Imperial University ed. Jubilee Publication in Commemorating Professor H. Yabe, M.I.A., Sixtieth Birthday: Institute of Geology and Paleontology, Tohoku Imperial University, Sendai, 289-299. Society of Tokyo 21: 33 .

Watanabe, M., and Kimura, M. 2002. Description and taxonomy of desmostylian fossils at 2nd site (4th and 5th excavation) in 1999 and 2000: pp. 54-75. In: Akan Animal Fossils Research Group ed. Reports from survey research of Akan Fauna 2: Akan Education Board, Akan-cho.

Yoshida, S., and Kimura, M. 2000. Description and taxonomy of desmostylian fossils at 2nd site (3rd excavation) in 1998. In: Akan Animal Fossils Research Group ed. Reports from survey research of Akan Fauna 2: Akan Education Board, Akan-cho, 29-53.

Yoshiwara, Y. and Iwasaki C. 1902. Notes on a new fossil mammal. Journal of the College of 


\section{Figure 1}

Composite cladogram showing the phylogenetic relationship among taxa examined in this study.

\section{A: Cladgram of Desmostylia with Sirenia (Tethyteria) as an outgroup. B: Cladgram of} Perissodactyla as an outgroup. Compiled from numerus sources, including Velez-Juarbe et al. (2012), Macfadden (1994) and Beatty (2009).

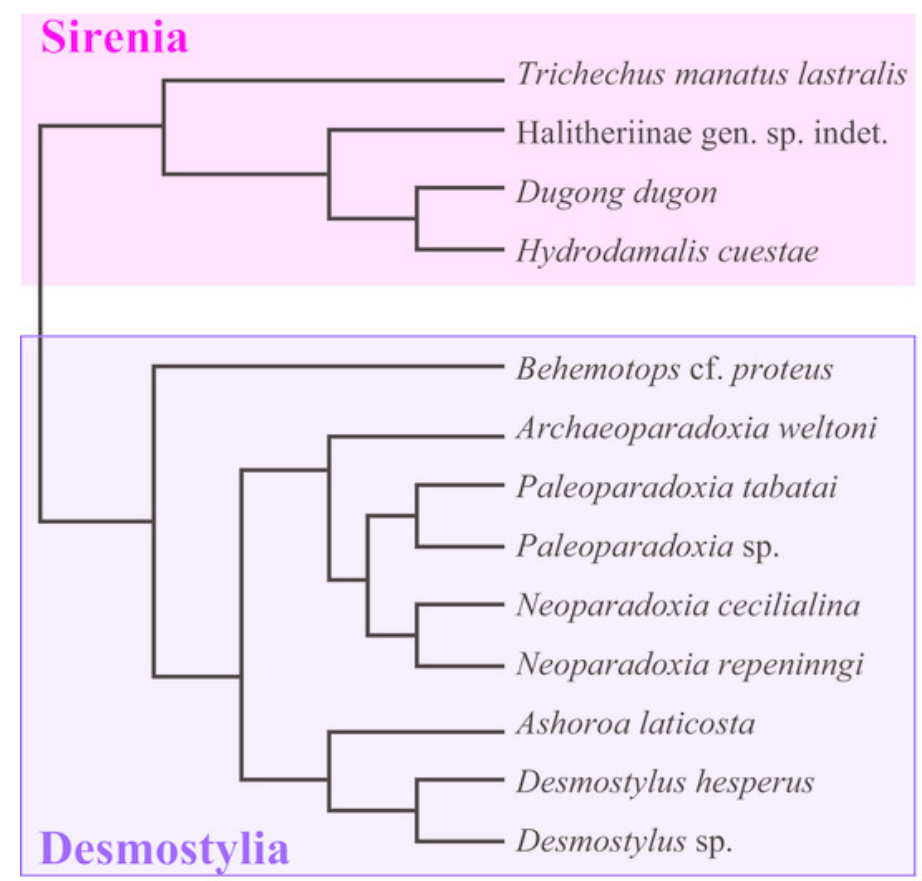

A

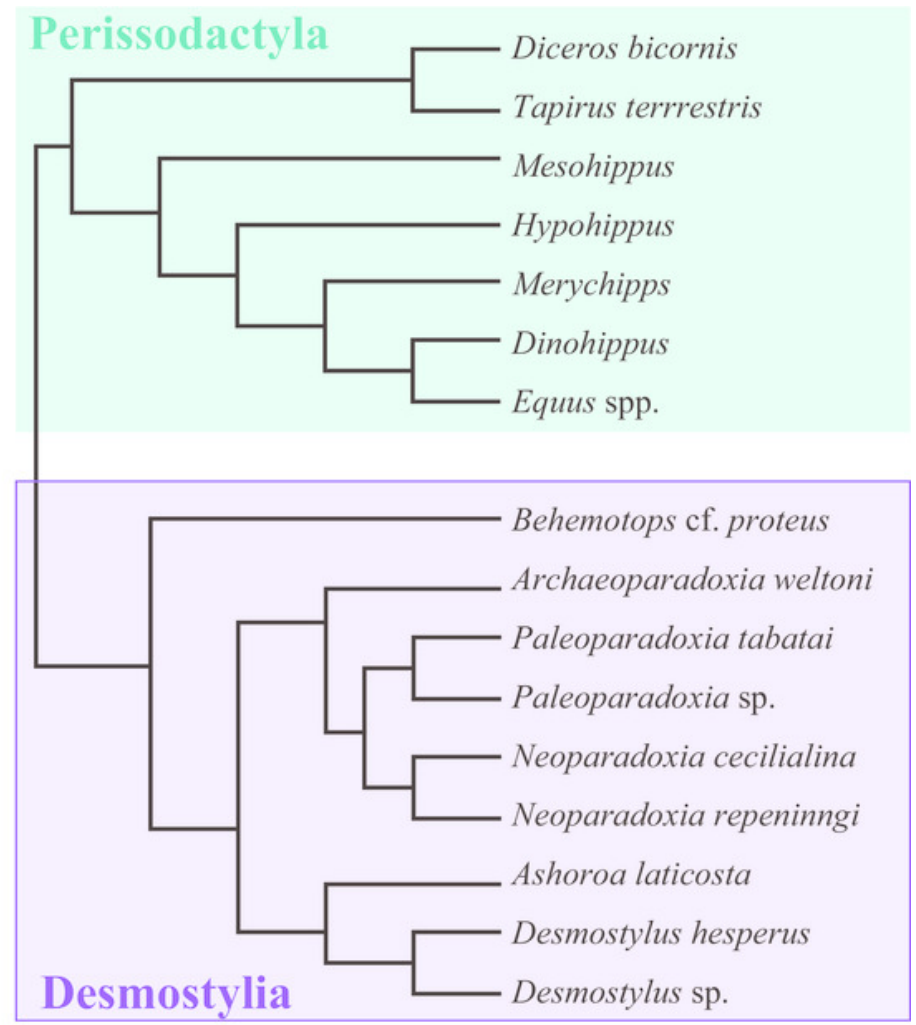

B 
Figure 2

Nomenclatures of humerus (based on Paleoparadoxia tabatai, NMNS PV 5601, and Paleoparadoxia sp., UMUT CV31059).

A: cranial side; B: lateral side; C: medial side; D: caudal side.
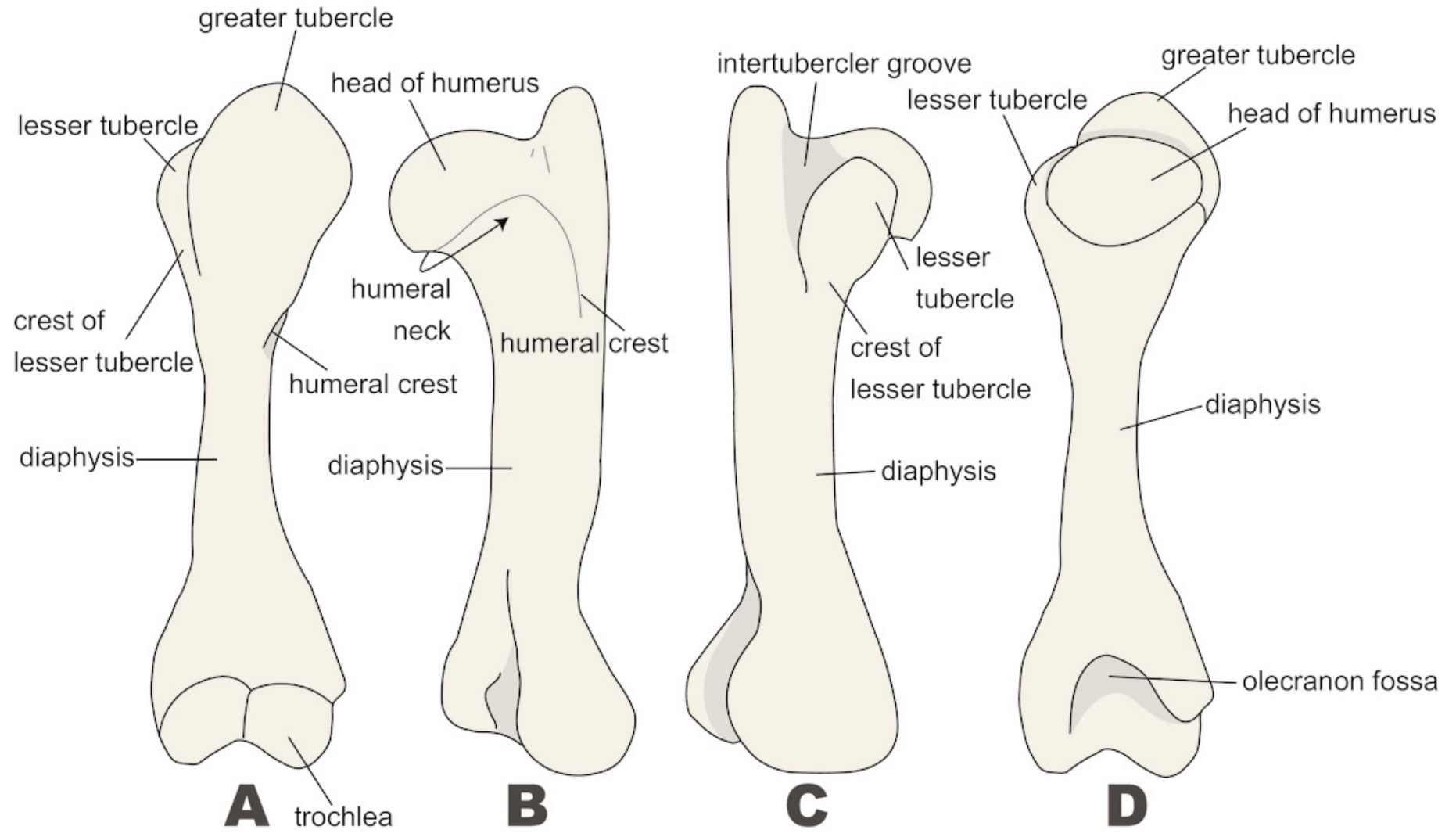
Figure 3

Diagnostic features of Desmostylia (based on Paleoparadoxia tabatai, NMNS PV 5601, and Paleoparadoxia sp., UMUT CV31059).

The distal part is illustrated based on NMNS PV 5601, and the proximal part is illustrated based on UMUT CV31059. Numbers are corresponding to the numbers in the text. 1:

Humerus diaphysis thicker than that in other relatives (red box); 2: Head of humerus larger than that in other relatives (green box); 3: Articular facet of head of humerus wider than in other relatives (yellow curve line); 4: Greater tubercle larger than other that in relatives (sky blue box); 5: Almost straight humerus diaphysis (salmon pink dotted line); 6: Trochlea larger than that in other relatives (dark blue box). A: cranial side; B: lateral side; C: medial side; D: caudal side.

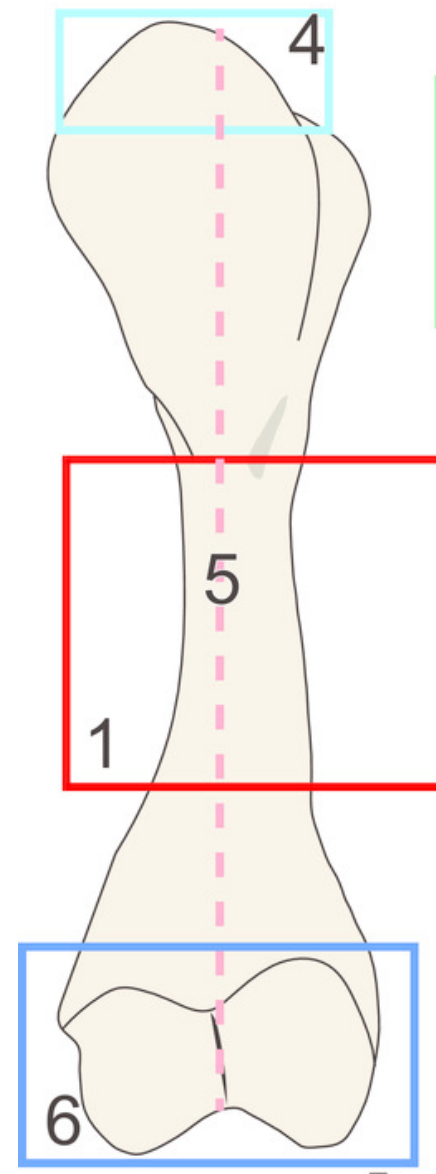

$\mathbf{A}$

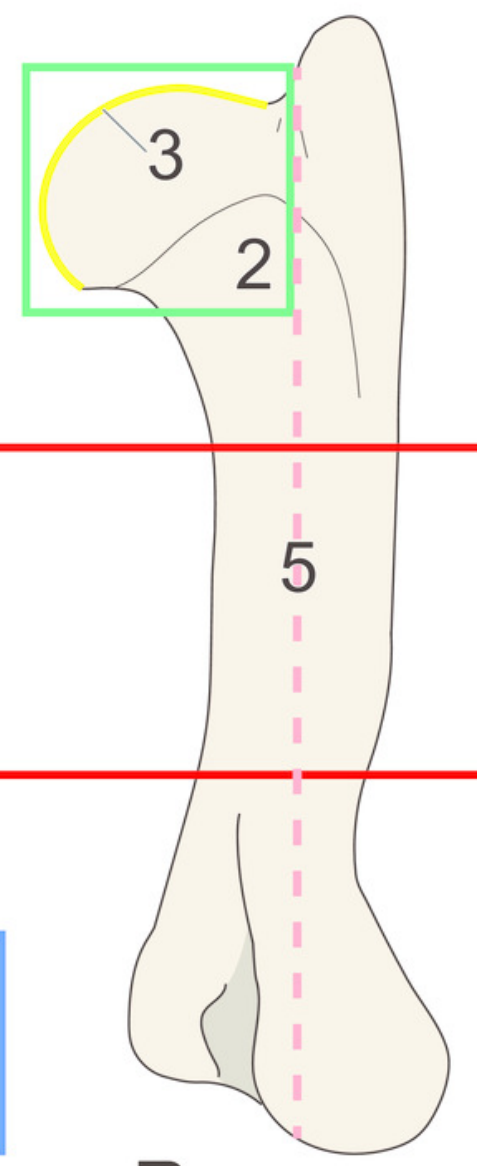

B

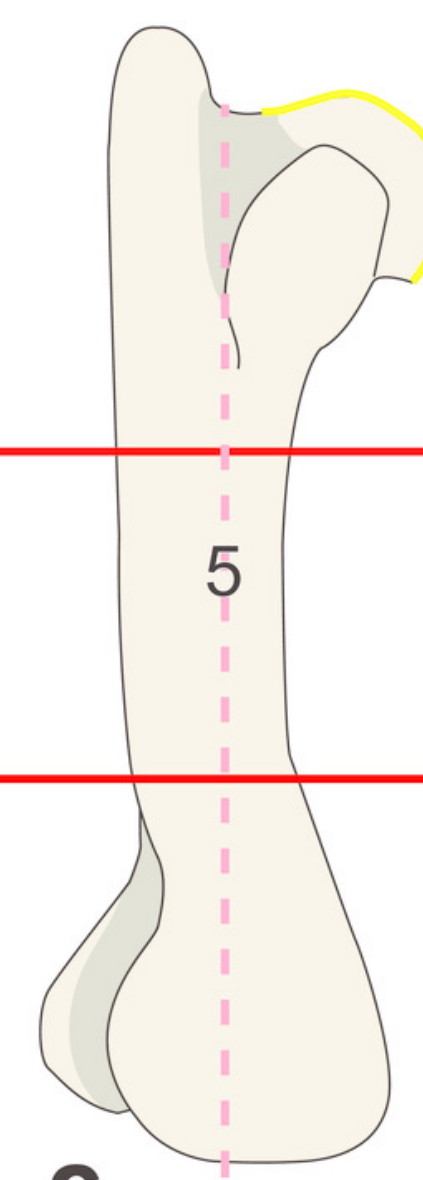

C
3

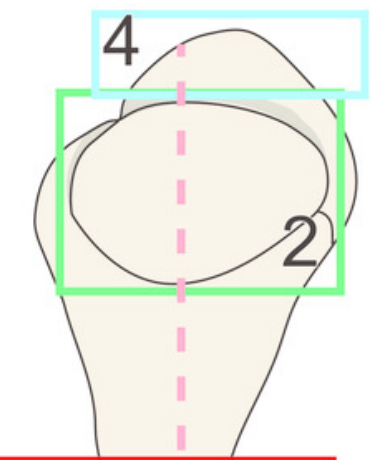

D 


\section{Figure 4}

Diagnostic features of Behemotops (based on Beatty and Cockburn, 2015).

Numbers are corresponding to the numbers in the text. Humeral diaphysis thinner than that in other desmostylians (red box); 2: Diaphysis curved on both mediolateral and caudal sides as in Trichechus (green dot line); 3: Head of humerus with larger angle than that in other desmostylians (yellow angle); 4: Shortest intertubercular groove in desmostylians (sky blue area); 5: Greater tubercle extending dorsally higher than head of humerus (lower than that in Paleoparadoxia, higher than that in Desmostylus, and similar to that in Ashoroa) (salmon pink box); 6: Humeral neck shallower than that in other desmostylians (dark blue arrow line). A: lateral side, B: cranial side. 


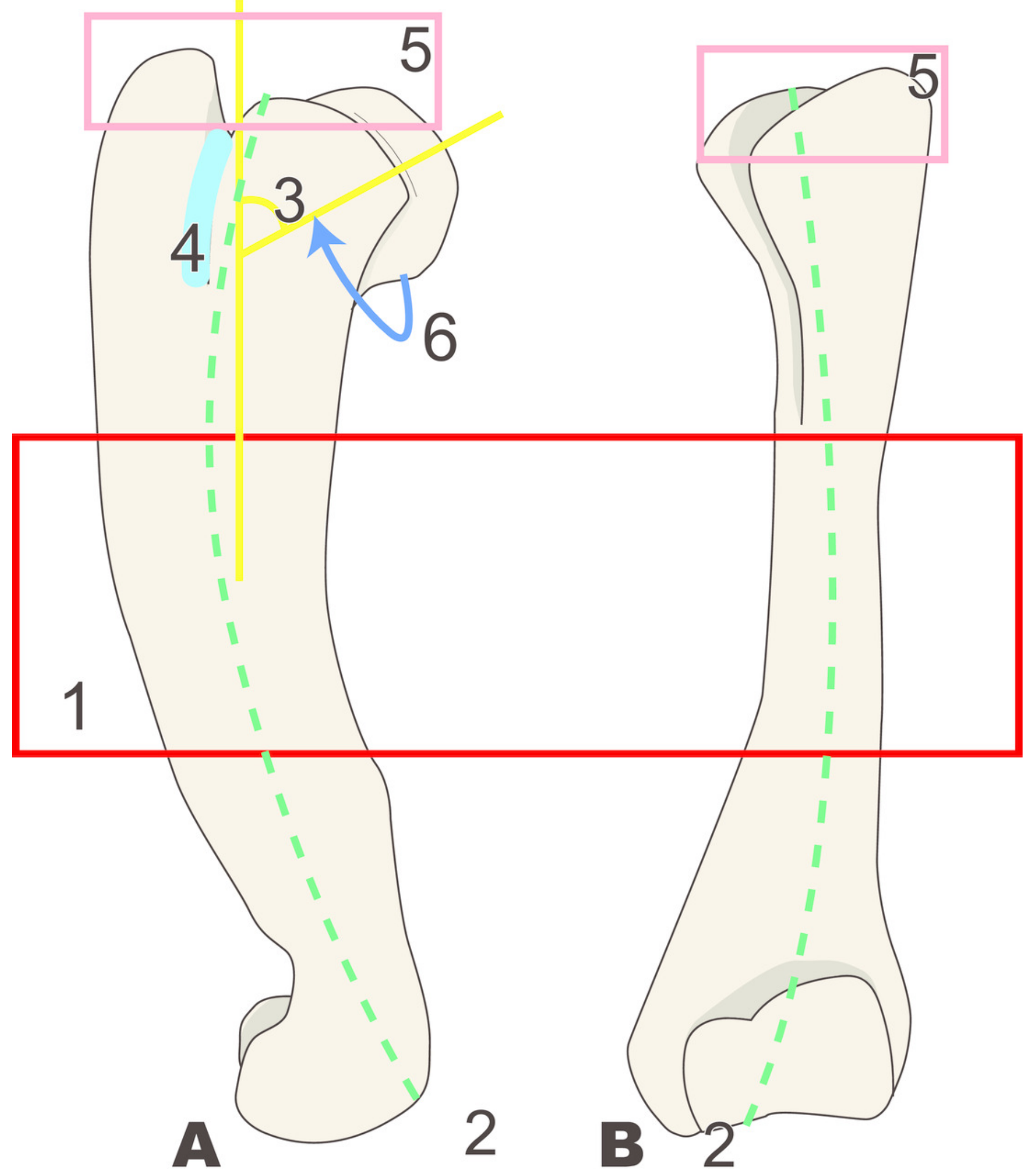




\section{Figure 5}

Diagnostic features of Archaeoparadoxia (based on UCMP114285). Numbers are corresponding to the numbers in the text.

1: Greater tubercle extending toward proximal side above the head of the humerus as in Paleoparadoxia (red box); 2: Wider greater tubercle than that in Desmostylus and Behemotops (green boxes); 3: Lesser tubercle distinct and smaller than that in Paleoparadoxia and medially projected, located on medial side like that in Paleoparadoxia (yellow area); 4: Intertubercular groove located on medial side and shallower than that in Neoparadoxia (sky blue box); 5: Trochlea smaller than that in desmostylids and other paleoparadoxiids, but slightly larger than trochlea of Behemotops (dark blue circle); 7:

Diaphysis slightly curved mediolaterally and caudally, unlike those of Paleoparadoxia and Desmostylus, but weaker than those of Ashoroa and Behemotops (purple boxes). A: cranial side; B: lateral side; C: medial side; D: caudal side. 


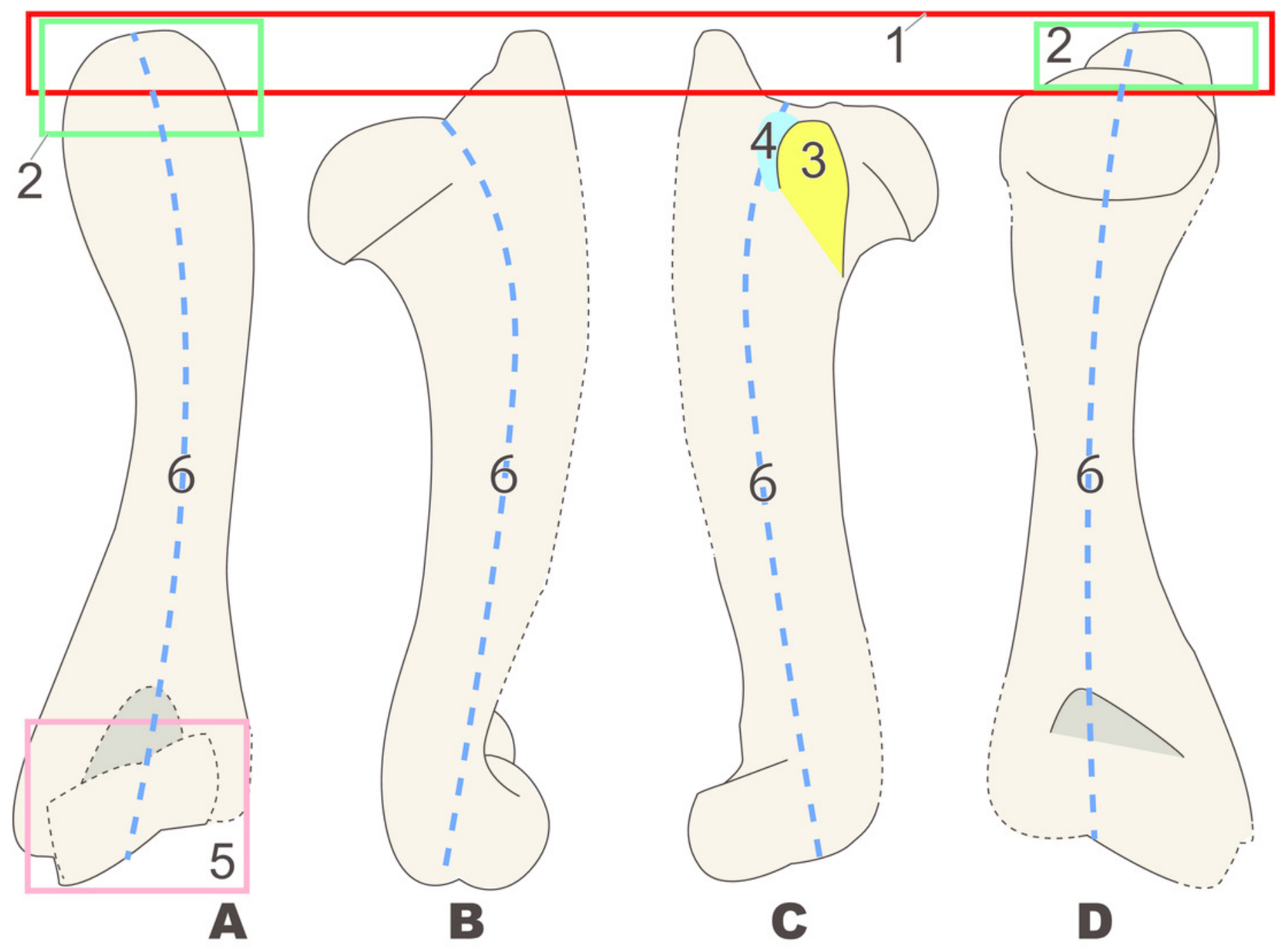




\section{Figure 6}

Diagnostic features of Paleoparadoxia (based on NMNS PV 5601 and UMUT CV31059).

The distal part is illustrated based on NMNS PV 5601, and the proximal part is illustrated based on UMUT CV31059. Numbers are corresponding to the numbers in the text. 1: Greater tubercle extending toward proximal side above the head of humerus (red box); 2: Greater tubercle wider than that in Desmostylus and Behemotops (green boxes arrow line); 3: Lesser tubercle distinct and medially projected, located on medial side (yellow area); 4: Intertubercular groove located on medial side (sky blue); 5: Shallow and narrow intertubercular groove (salmon pink area); 6: Head of humerus oval-shaped and slightly convex at distal end (dark blue circle); 7: Absence of well-developed deltoid tuberosity (purple boxes). A: cranial side; B: lateral side; C: medial side; D: caudal side. 


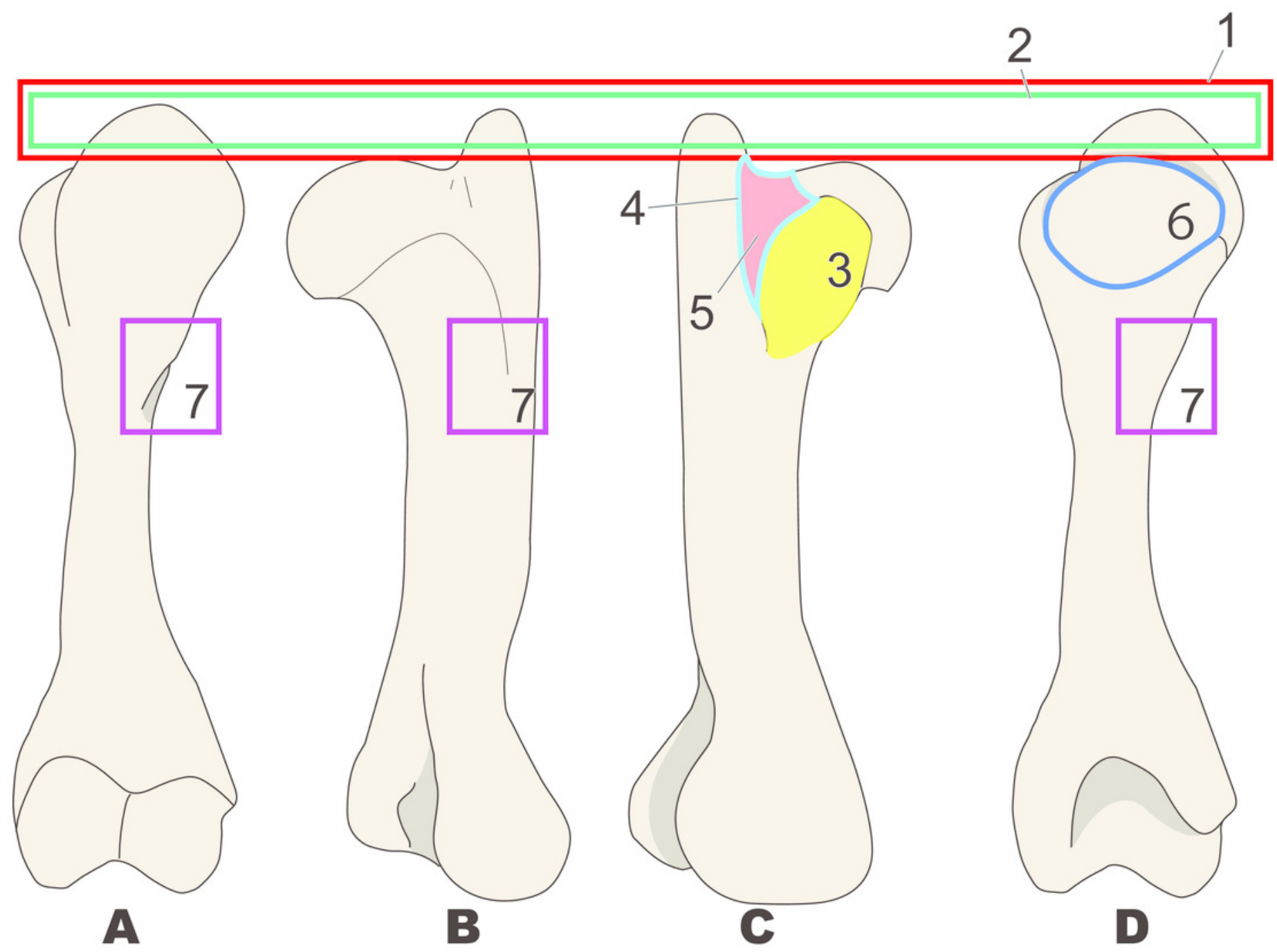




\section{Figure 7}

Diagnostic features of Neoparadoxia (based on LACM 150150 and NMNS PV 20731).

The proximal part is illustrated based on LACM 150150, and the distal part is illustrated based on NMNS PV 20731. Numbers are corresponding to the numbers in the text. 1: Greater tubercle developed as crest, stronger than that in in Paleoparadoxia (red box); 2: Humeral crest strongly developed and extending distally over half of whole humerus (green line); 3: Head of humerus oval, wider than that in Paleoparadoxia, and not convex at distal end unlike in the Paleoparadoxia (yellow area); 4: Intertubercular groove wider than that in Paleoparadoxia, but narrower than that in Desmostylus (sky blue line). A: cranial side; B: lateral side; C: caudal side. 

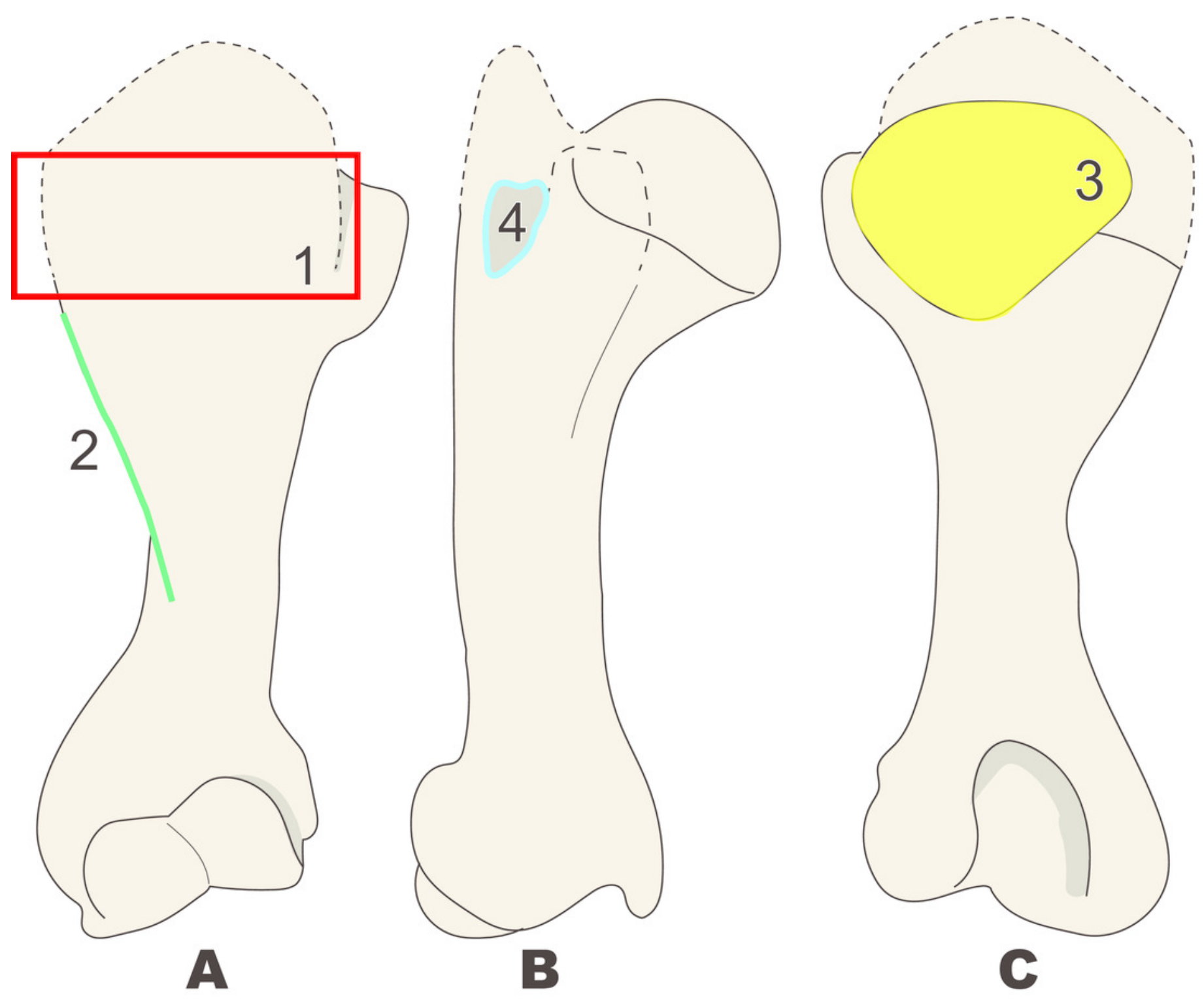


\section{Figure 8}

Diagnostic features of Ashoroa (based on AMP21). Numbers are corresponding to the numbers in the text.

Numbers are corresponding to the numbers in the text. 1: Constriction of humeral neck shallower in desmostylians, but deeper than that in Behemotops (red arrow line); 2: Lesser tubercle only slightly less developed than that in Archaeoparadoxia, Paleoparadoxia, and Neoparadoxia (green area); 3: Intertubercular groove shorter than that in Archaeoparadoxia, Paleoparadoxia, Neoparadoxia, and Desmostylus (yellow area); 4: Diaphysis loosely curved like that in Behemotops, but stronger than that in Archaeoparadoxia (sky blue dot line); 5 : Humeral crest more strongly developed than that in Paleoparadoxia and extending distally just above trochlea (salmon pink line); 6: Lesser tubercle located and developed on cranial side (dark blue). A: cranial side; B: lateral side; C: medial side; D: caudal side. 

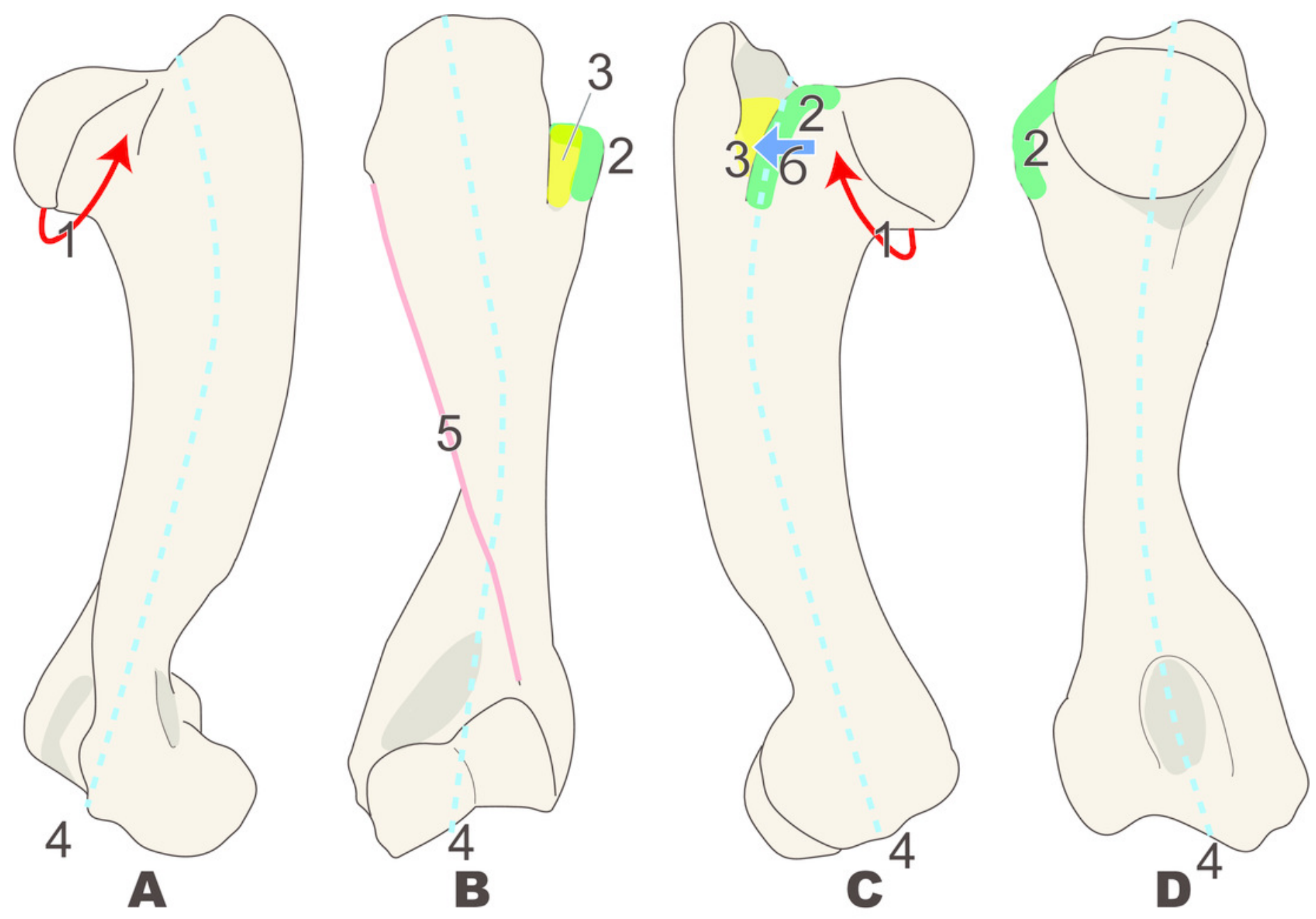


\section{Figure 9}

Diagnostic features of Desmostylus (based on UHR 18466, GSJ-F7743, and OME-U0170).

The proximal sides of the dorsal and ventral views are illustrated based on UHR 18466, the medial side and distal part is illustrated based on UHR 18466 but has been slightly modified based on OME-U-0170 and GSJ-F7743. Numbers are corresponding to the numbers in the text. 1: Intertubercular groove located just behind head of humerus on cranial side (red circle); 2: Shallow and v-shaped intertubercular groove (green area); 3: Lesser tubercle smaller than that in other desmostylians (yellow area); 4: Lesser tubercle not projecting to medial and cranial sides (sky blue arrow line); 5: Crest of lesser tubercle well-developed and extending ventrally (salmon pink area); 6: Greater tubercle and head of humerus almost the same height (= greater tubercle not projecting higher than head of humerus) (dark blue box). A: cranial side; B: caudal side; C: lateral side. 

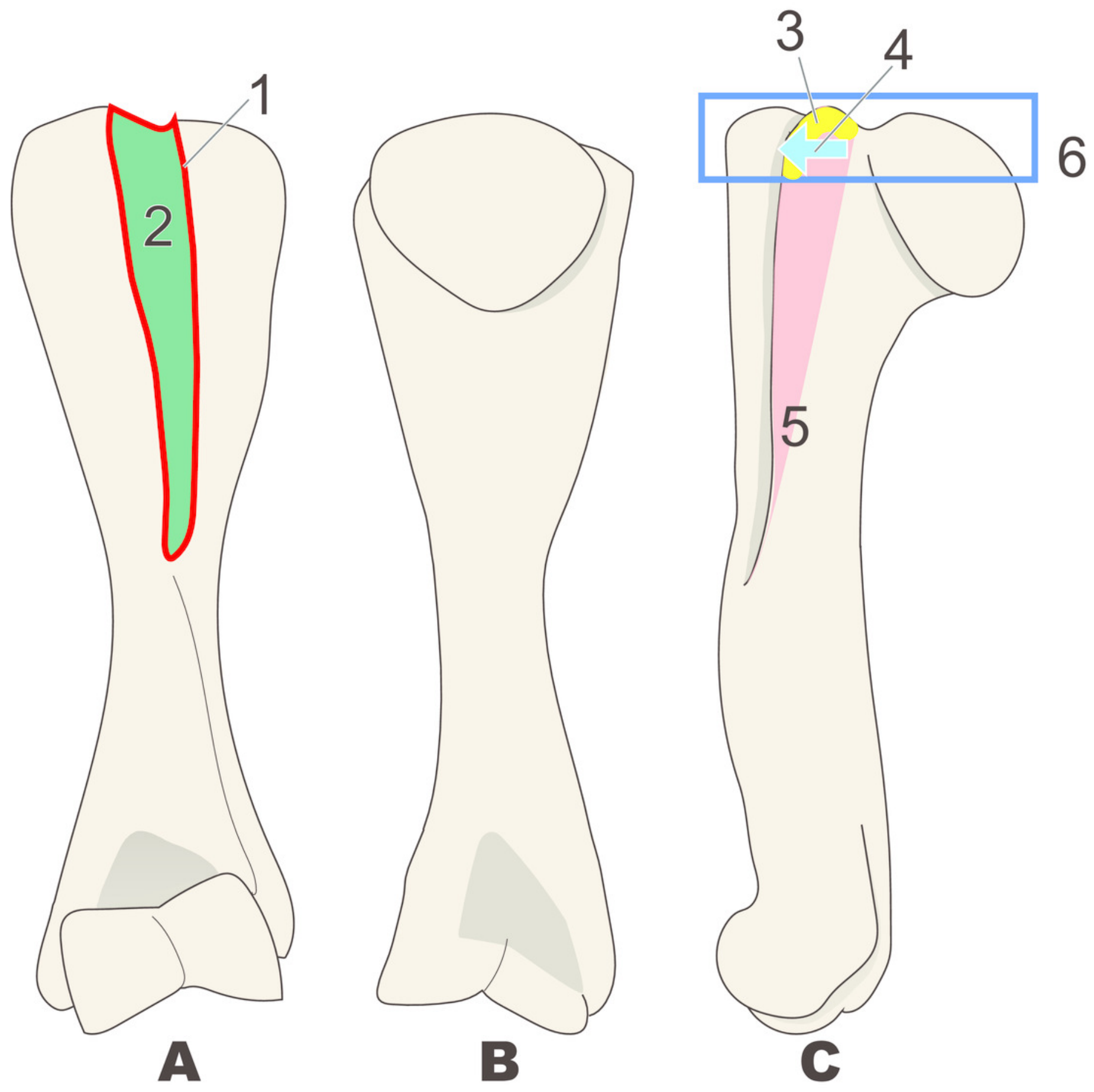